\title{
ニューラルネットワークによる最短経路問題の 実時間制御への適用法の提案*1
}

\author{
河 東 晴 子*2, 田 中 健 - ${ }^{* 3}$, 大 島 一 能*4
}

三菱電機 $($ 株） 情報技術総合研究所*2, 先端技術総合研究所*3, 情報通信システム開発センタ*4

\section{An Implementation Method of the Shortest Path Problem to the Real Time Control Using Neural Network}

\author{
Haruko Kawahigashi*2, Ken-ichi Tanaka*3, Kazuyoshi Oshima*4 \\ Information Technology R \& D Center*2, Advanced Technology R \& D Center*3, \\ Information \& Communication Systems Development Center*4, Mitsubishi Electric Corp.
}

It is known that there exist polynomial-time solutions to the shortest path problem. However, these algorithms are assumed to be run on the processors, and difficult to be applied to the real time control because of the time limitation. This paper proposes an implementation method of the shortest path problem to the real time control using neural network. The proposed method can be implemented by hardware digital logic circuits, and enables the shortest path design to be 4 to 6 digits faster than the conventional algorithms. The proposed method is also easily implemented by LSI.

\section{1.はじめに}

最短経路問題は 2 地点間の最短経路を求める問題 で，連続場，離散系など種々の場合について検討され ている。本論文では，通信ネットワークのような離散 系 ( 2 章で詳述) に抢ける最短経路問題を取り扱う。な お, 本論文では, ネットワークという言葉が， 2 章で 述べるネットワークと，ニューラルネットワークの 2 つの意味で使われる。これらを区別するために，前者 を通信ネットワーク，後者をニューラルネットと呼 ぶ.

最短経路問題にはダイクストラ法等の多項式時間の アルゴリズムが存在しているが，これらのアルゴリズ ムは計算機の使用を前提としていて, 高速性が求めら れる実時間制御への適用は困難であった。

一方, ニューラルネットは, 2 值性, 空間的加算性 等の特徵により電子回路と整合性の良いものであり, アナログ電子回路によるニューラルネットは従来から

\footnotetext{
${ }^{* 1} 1996$ 年 10 月 2 日受付

${ }^{* 2} \mathbf{\mathrm { T }} 247$ 鎌倉市大船 5-1-1

$* 3 \% 661$ 尼崎市塚口本町 8-1-1

${ }^{* 4}$ 个 247 鎌倉市大船 5-1-1
}

研究されてきた1,2).

本論文では，ニューラルネットを用いて，最短経路 問題を実時間制御システムに適用する方式を提案す る. 提案方式は, ハードウエアディジタル論理回路で 容易に実現することができるという特長を有し，これ により，従来の多項式時間アルゴリズムに比べて，4 桁〜 6 桁高速化が可能である.また LSI 化により高 集積化も可能である。えに提案方式により, 従来の 方式では時間的にも処理資源的にも最適化計算が不可 能であった通信ネットワーク制御等の分野での最適化 が可能となる。

本論文で提案する方式は動的計画法を適用したもの であるが, 従来の研究で動的計画法をニューラルネッ 卜に適用して最適経路設計を行う例としては, Lemmonによるロボット軌道制御 ${ }^{3}$ がある。これはロボ ットの可動領域 (2 次元)に, 格子状に二ューロンを配 置し, 最短距離を通ってロボットが 2 地点間を移動す る経路を求める方法であり, 文献 4)で解説されてい る、このモデルでは，ニューロン間の結合は無向性で かつ等荷重となっている.この無向性・等荷重の仮定 のもとでの議論は，2 次元平面上にニューロンを敷き つめるロボット軌道の場合には有効であるが, 通信ネ 
ットワークでは有効性が小さい5)。これに対し本論文 で提案する最短経路問題の解法では，ノードに割付け たニューロン間の結合に方向と荷重を付加することが できる.

本論文の構成は，まず 2 章で通信ネットワークモデ ルを示し課題設定を行い, 次に 3 章でニューラルネッ トによる解法を提案する。 そして 4 章でこの提案方法 の理論的根拠である動的計画法による解法を記す。さ らに 5 章で提案方式のディジタル論理回路による実現 法を示し，提案方式の評価を行なった後，提案方式の 有効性について述べる.

\section{2. 通信ネットワークモデル}

通信ネットワークの構成はノード (node, 節点) と, ノード間を接続するアーク ( arc，枝)である，ネット ワークモデルとして， $1, \cdots, n$ の $n$ 個のノードと, ノード間を接続するアークとから構成されるネットワ ークを考える。ノード $i$ から $j$ へ向かうアークをアー ク $(i, j)$ と呼ぶ。すべてのアークには方向性があると する。ノード $i$ から出るアーク $(i, j)$ が向かう先のす ベてのノード $j$ の集合を $A(i)$ と記し， $A(i)$ を $i$ の隣

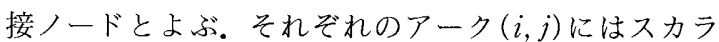
值 $a_{i j}$ が付与され， $(i, j)$ の「コスト」と呼ばれる. 一般に, コストはアークの距離など, 任意の属性とし てよい. 図1(a)にノード数が 9 の通信ネットワーク の例を示す．図1（a)の例では簡単のためアークに方 向性がないものとしている.

経路 $\left(i, i_{1}\right),\left(i_{1}, i_{2}\right), \cdots,\left(i_{m}, j\right)$ のコストは，経路中の アークコストの和 $\left(a_{i i_{1}}+a_{i_{1} i_{2}}+\cdots+a_{i_{m-1} i_{m}}+a_{i_{m}}\right)$ と定 義する。本論文の課題は各ノード $i$ 加あて先ノード $d$ への総コストが最小となる経路を探索することであ る、ここでは，まず，(1)アークの容量は考えない， （2）ノードにはコストは付与しない，なる制約をつけ て議論を進めるが，以下の議論はこの制約を取り払つ た場合でも有効で，後に制約無しの場合についても言 及する。

\section{3. ニューラルネットワークによる解法}

\section{1 ニューラルネットの構成}

ここで提案するニューラルネットは $n$ 個のニュー ロンで構成されており，通信ネットワークとトポロジ 一的に同じ構造をしている。ニューロン $i$ はノード $i$ と一対一に対応している. 各々のニューロン $i$ は他の ニューロンと方向性のあるシナプスにより結合し， シ ナプス結合はアークに対応する。ニューロン $i$ からニ ューロン $j$ へのシナプス結合荷重を $w_{i j}$ と記す。通信
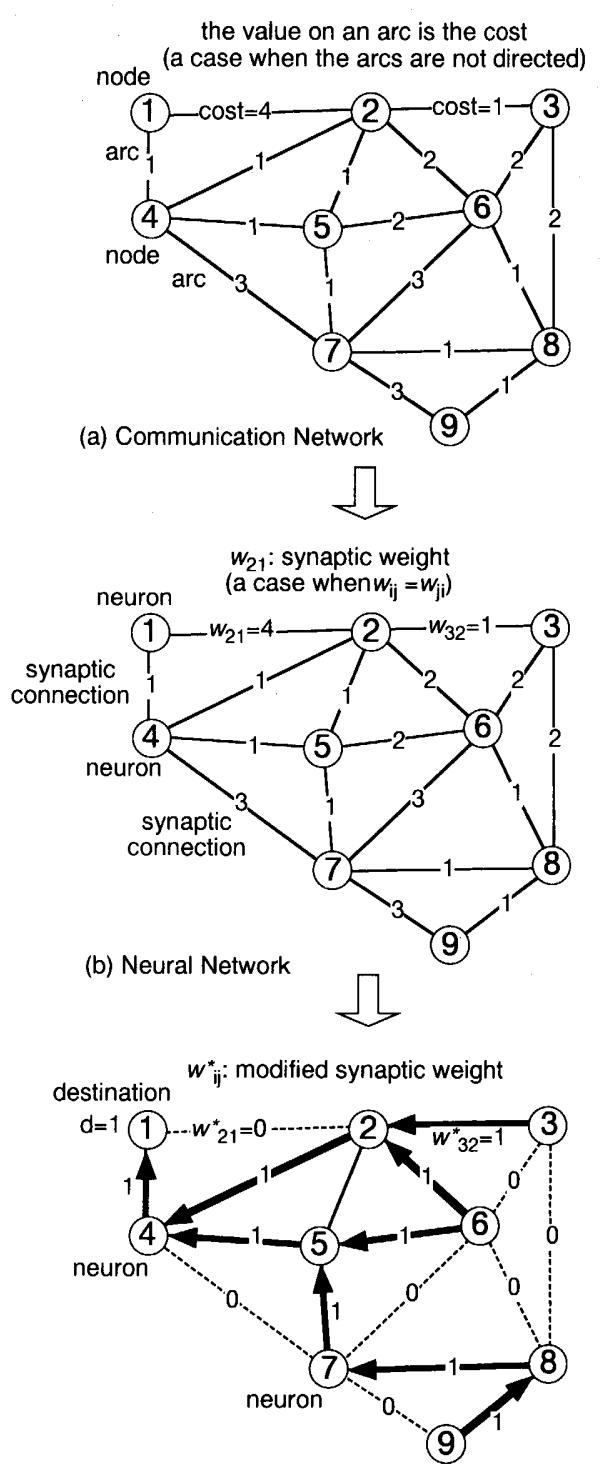

(c) The Most Efficient Network of destination $=1$

Fig. 1 Network examples. (a) Communication network：2 章で説明している通信ネットワ ークの例, (b) Neural network : 3.1 節で説 明しているニューラルネット((a)に対応), (c) The most efficient network of destination=1:3.3 節で説明している最効率的ネッ トワーク ( ( a ) に対応)

ネットワークの場合には, ノード $i$ と $j$ 間のアーク 結合を表現するのに隣接ノード $j \in A(i)$ およびアー クコスト $a_{i j}$ を用いたが，ニューラルネットの場合に は，シナプス荷重を次のように設定する。 


$$
w_{i j}= \begin{cases}a_{i j} & \text { if } j \in A(i) \\ 0 & \text { if } j \notin A(i)\end{cases}
$$

$w_{i j}$ は非負の整数值をとるとする。図 1(a)の通信ネ ットワークに対応するニューラルネットを図 1 ( b ) に 示す.

\section{2 ニューロンのダイナミクス}

上記のニューラルネットにおいて，二ューロン $i$ の 時刻 (更新繰返し数) $k$ に扔ける出力を $x_{i}^{k}$ と記し, 二 ューロン $i$ が活性のとき $x_{i}^{k}=1$, 不活性のとき $x_{i}^{k}=0$ とおくとする。

すべてのニューロンを不活性とした後，あて先ノー ド $d$ に対応するニューロン $d$ に刺激を与えたとき, この刺激はニューロンを一個ずつ活性化しながら，伝 搬していく，各結合に打いて，シナプスによって伝搬 は遅延を受け，その遅延量はシナプス荷重に比例す る.ネットワーク全体に刺激が伝搬したとき，ニュー ラルネット中のすべてのニューロンが活性化されてい る.

上記の手順は，次のように表すことができる.

$$
\begin{aligned}
& x_{i}^{k}= \begin{cases}\text { 活 性 } \quad i \neq d \text { で, } x_{j}^{k-w_{i j}} \text { が活性な } \\
& \text { 隣接ニューロン } j \text { が存在する場合 } \\
\text { 不活性 } i \neq d \text { で, 上記以外の場合 }\end{cases} \\
& x_{d}^{k}=\text { 活性. }
\end{aligned}
$$

但し初期条件は $x_{d}^{0}=$ 活性, $i \neq d$ の場合は $x_{i}^{0}=$ 不活 性とする。また， $k-w_{i j}<0$ の場合は $x_{j}^{k-w_{i j}}=$ 不活性 とする。後で証明するように， $x_{i}^{k} は 一$ 度活性化した ら不活性には㞍らない。

上式はまた，次のように表すこともできる。

$$
\begin{aligned}
& x_{i}^{k}=G\left[\sum_{j=1}^{n} w_{i j} \cdot x_{j}^{k-w_{i j}}\right], \text { for } i \neq d, \\
& x_{d}^{k}=1 .
\end{aligned}
$$

但し, $x>0$ のとき $G(x)=1, x \leq 0$ のとき $G(x)=0$ と する.これをニューロン $i$ のダイナミクスを示す神経 方程式とよぶ.上式において，ニューロン $j$ から $i$ へ の影響は，空間的に係数 $w_{i j}$ で重み付けされ，時間的 に係数 $w_{i j}$ で遅延される. 図 1 ( b ) の二ューロンの出 力 $x_{i}^{k}$ の $k$ による変化を表 1 に示す.

\section{3 最も効率的なネットワークの学習}

次に, 提案する二ューラルネットの学習の仕方につ いて以下に説明する。ここで提案する方式は，教師な し学習である。

まず最初にニューロン $d$ に刺激を与え，前節で述 ベたように伝搬させる。ニューロン $i$ は, 隣接ニュー ロンから，シナプス結合を通して伝搬してくる刺激を 受信する。伝搬されてくる刺激の中で，一番最初に到 着したものがニューロン $i$ を活性化し，その後刺激を
Table 1 Change of the output. ニューロンの出力 $x_{i}^{k}$ の 時刻 $k$ による変化を示 した遷移表 (3.2 節で説 明)

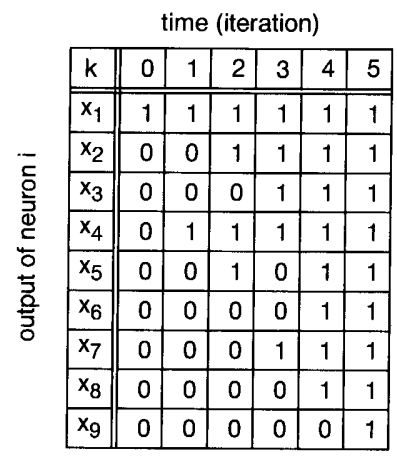

受信したときにはニューロン $i$ は既に活性化されてい るので, 結果的には, 後着刺激は二ューロン $i$ に影響 を与えない. 故に, 二ューロン $i$ を活性化した隣接二 ューロンおよびその隣接ニューロンからの結合が, 二 ユーロン $i$ に対して最大の影響力を持っていると言っ てよい.そこで，ニューロン $i$ は最大の影響力を持つ 隣接ニューロンからのシナプス結合を強化する。この ようにして，ニューロン $i$ は最大の影響力を持つ結合 を記憶する，結果として，強化された結合のみが勝っ て生き残り，他の結合は負けて衰退してしまう。ネッ トワーク全体で生き残った結合のみを集めたものは, ニューロン $d$ にえられた刺激をニューラルネット 全体に伝搬する目的のためには，最も効率的なネット ワークとなる。なぜならこのネットワークには, 敗退 する結合がはじめから存在しないからである。このネ ットワークを, 最効率的ネットワーク (the most efficient network) と呼ぶ。図 1(a)の通信ネットワ 一クに対応する最効率的ネットワークを図 1 (c)に示 す.

ニューロン $i, j$ 間のシナプス荷重 $w_{i j}$ が学習あるい は記憶によって $w_{i, j}^{*} に$ 変形するとし, 勝残の場合 $w_{i j}^{*}$ $=1$, 敗退の場合 $w_{i j}^{*}=0$ とおくと, 上記の内容は次の ように表すことができる。式 (2) あるいは式 (3)に従 ってニューロン $i$ の出力 $x_{i}^{k}$ が変化するとき, $j \neq d$ の 場合は,

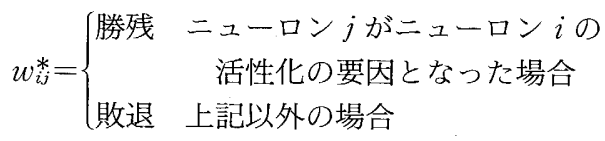


また, ニューロン $d$ は隣接ニューロンから活性化さ れたのではなく, 最初から活性とおいたので, $w_{i d}^{*}=$ 空集合となる.

上式はまた，次のように表すこともできる。

$j \neq d$ の場合は,

$$
w_{i j}^{*}=G\left[\sum_{k} \sum_{j=1}^{n}\left|x_{i}^{k}-x_{i}^{k-1}\right| \times w_{i j} \cdot x_{j}^{k-w_{i j}}\right]
$$

また， $w_{i d}^{*}=$ 空集合となる。これを記憶方程式とよ ぶ. 上式(5)に扔いて係数 $w_{i j} \cdot x_{j}^{k-w_{i j}}$ は, 式(3)に示 すように，二ューロン $j$ から $i へ の$ 影響を示し，係数 $\left|x_{i}^{k}-x_{i}^{k-1}\right|$ によって $x_{i}^{k}$ が変化したときのみ有効とな る.

\section{4 アルゴリズム}

以上の議論をもとに，ニューラルネットにより最小 コスト経路を得るアルゴリズムを次のように提案す る。

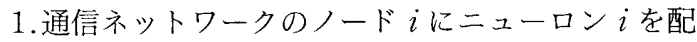
置し, 式(1)に従ってシナプス結合荷重を設定す る. 各ニューロンの出力を $x_{d}^{0}=1$ (活性),$i \neq d$ の場合は $x_{i}^{o}=0$ (不活性) と初期化する.

2.更新を開始し, 各ニューロンの出力 $x_{i}^{k}$ を神経方 程式 (3) に従って更新した後, シナプス荷重 $w_{i j}$ を記憶方程式 $(5)$ に従って $w_{i j}^{*}$ に更新し，交互に これを繰返す。

3.すべてのニューロンが活性化されたら, 更新を停 止する。そこであて先 $d$ に基く $w_{i j}^{*}$ の集合，す なわち最効率的ネットワークが得られる。

4. 発信元 $s$ からあて先 $d$ への個々の最適経路は, 最効率的ネットワークを $s$ から $d$ ヘノード毎に たどることによって得られる。

5. 異なるあて先 $d$ についてはステップ 1 から 3 ， 異なる発信元 $s$ につてはステップ 4 を繰返す。

このアルゴリズムでは, 簡単のために, 全ニューロ ンが活性化した際に繰り返しを停止することとしたの で，ネットワーク全体についての $d$ に基いた最効率 的ネットワークを得ることができる。しかし特定の発 信元 $s$ からの経路を求めることのみが目的であるなら ば，ニューロン $s$ が活性化した際に繰り返しを止めて もよい.

\section{5 バリエーション}

前章で述べたアルゴリズムはアークコストのみを考 慮して抢り，アーク容量とノードコストについては考 慮していなかった。しかし式 (1)のシナプス荷重を変 更することによって，アルゴリズムを一般化して使用 することができる。

\section{5 .1 アークの容量を考慮する場合}

第一の例として，通信ネットワークの各アークにお いて，コストだけでなく容量をも考慮する場合につい て述べる。「容量」とは各アーク $(i, j)$ に付与されるス カラ值 $\phi_{i j}$ で，次の性質を持つものとする.

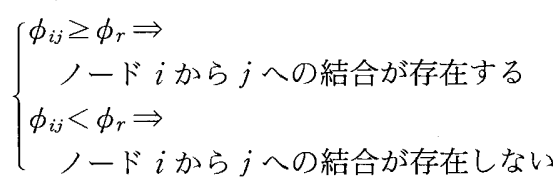

但し $\phi_{r}$ は「要求容量」である. 要求容量 $\phi_{r}$ は通信 ネットワーク全体に付与されるスカラ量で，容量 $\phi_{i j}$ $\geq$ 要求容量 $\phi_{r}$ の場合にはアーク $(i, j)$ はその要求を 通すことができるが， $\phi_{i j}<\phi_{r}$ の場合には，その要求 を通すことができない。後者の場合には，アーク $(i$, j) は要求を満たさないので, 存在しないのと等価に なる。容量は，アークの使用可能性をチェックするた めだけに用いられ，コストとは独立である．

容量を考慮した場合のシナプス結合荷重は，次のよ うになる。

$$
w_{i j}= \begin{cases}a_{i j}, & \text { if } j \in A(i) \text { and } \phi_{i j} \geq \phi_{r}, \\ 0, & \text { if } j \notin A(i) \text { or } \phi_{i j}<\phi_{r} .\end{cases}
$$

\section{5 .2 ノードのコストを考慮する場合}

第二の例として，アークだけでなくノードのコスト をも考慮する場合について述べる。

次式 ( 8 ) に示すようにアークコストの概念を拡張す ることにより，ノードにもコストを付与することがで きる。

$$
a_{i j}=\bar{a}_{i}+\bar{a}_{i j}
$$

但し $\widehat{a}_{i}$ はノード $i$ のコスト, $\bar{a}_{i j}$ はアーク $(i, j)$ のコ ストである。証明は 4.4 節に示す。ここでは， $\widehat{a}_{d}=0$ と扔く必要がある。

\section{4. 動的計画法による解法}

本章では，3章で提案したアルゴリズムの理論的根 拠である動的計画法による解法を示す。

\section{1 動的計画法による最小コスト経路の探索}

2 章で述べた通信ネットワークモデルに扔いて，最 小コスト経路のコスト $x_{i}^{*},(i=1, \cdots, n)$ は, 次のベル マン方程式によるシステムの唯一の解である.

$$
\begin{aligned}
& x_{i}^{*}=\min _{j \in A(i)}\left(a_{i j}+x_{j}^{*}\right), \text { for } i \neq d, \\
& x_{d}^{*}=0 .
\end{aligned}
$$

さらに，ベルマン・フォードアルゴリズムによれ ば，次式(10)に従った更新を繰り返せば， $x_{d}^{k}=0$ なる 任意の初期ベクトル $x$ について, 上式 $(9)$ の解に収 束する。 
$x_{i}^{k}=\min _{j \in A(i)}\left(a_{i j}+x_{j}^{k-1}\right)$, for $i \neq d$,

$x_{d}^{k}=0$.

ここでは, 初期值を $x_{d}^{0}=0, i \neq d$ なる $i$ にいては $x_{i}^{0}$ $=\infty$ とおく.このアルゴリズムは, すべての $i$ につ いて $x_{i}^{k}=x_{i}^{k-1}$ となる繰り返し回数 $k$ の後, 終了とす る6).

\section{2 単位コストアークネットワーク}

ここで次の仮定をおく.

仮定 1 (単位コストアーク) すべてのアークのコスト

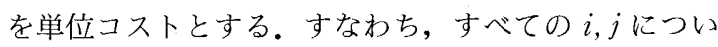
て, $a_{i j}=1$ とする.

この場合, ベルマン方程式 ( 9 ) は次のようになる. $x_{i}^{*}=\min _{j \in A_{1}(i)}\left(1+x_{j}^{*}\right)=1+\min _{j \in A_{1}(i)} x_{j}^{*}$, for $i \neq d$, $x_{d}^{*}=0$

但し $A_{1}(i)$ は，単位コストアークネットワークにおけ るノード $i$ の隣接ノードの集合とする。

また，ベルマン・フォードアルゴリズム (10) は次の ようになる。

$$
\begin{aligned}
& x_{i}^{h}=1+\min _{j \in A_{1}(i)} x_{j}^{k-1}, \text { for } i \neq d, \\
& x_{d}^{k}=0 .
\end{aligned}
$$

次に $i \neq d$ なる $i$ において， $x_{i}^{k}$ が初めて初期值から 更新されるときの繰り返し数 $k$ を $k_{i}$ と定義する.す なうち，

$$
\begin{aligned}
& x_{i}^{k}=\infty \text { for all } k \leq k_{i}-1 \\
& x_{i}^{k_{i}} \neq \infty .
\end{aligned}
$$

また， $k_{d}=0$ とする.

$k_{i}$ は, 次の命題に示す特徴を持つ.すなわち, 八 一ド $i$ に打いて, $x_{i}^{k}$ が繰り返し数 $k_{i}$ で初期值 $\infty$ か ら $x_{i}^{k_{i}}$ に始めて更新されたとき， $x_{i}^{k_{i}}$ は $k_{i}$ に等しく, また最小コスト経路のコスト $x_{i}^{*} に も$ 等しい. $x_{i}^{h_{i}}$ は その後の繰り返し $k>k_{i}$ では変化しない.

命題 1 各ノード $i$ に扔いて,

$$
\begin{aligned}
& k<k_{i} \Rightarrow x_{i}^{k}=\infty \\
& k \geq k_{i} \Rightarrow x_{i}^{l}=k_{i}=x_{i}^{*} \text { for all } l \geq k .
\end{aligned}
$$

証明 1 式(14)は $k_{i}$ の定義により成立. 式(15)に ついては, 数学的帰納法により証明する.

まず， $k=1$ の場合について検証する.すべての $d$ $\in A_{1}(i)$ なる $i$ について， $k_{i}=1$ が成立する. 故に式 (11)と(12)から, すべての $l>k=1$ について, $x_{i}^{*}=$ $x_{d}^{l}+1=1$ が成立する.このとき， $d \oplus A_{1}(i)$ なるすべ ての $i$ については, $k_{i}>1$ と $x_{i}^{l}=\infty$ が成立する. 故に $k=1$ の場合には式(15)が成立する.

式(15)が $k>1$ の場合に成立すると仮定し， $k+1=$ $k_{i}$ の場合について検証する. 式(12)と $k_{i}$ の定義 (13) から $x_{i}^{k+1}=1+\min _{j \in A_{1}(i)} x^{k} \neq \infty$ が成立し, またすべ
ての $l \leq k$ について $x_{i}^{l}=1+\min _{j \in A_{1}(i)} x^{l-1}=\infty$ が成立 する. 故に, すべての $l \leq k$ と $j \in A_{1}(i) k つ い て ~ x_{j}^{l-1}$ $=\infty$ が成立する.さらに，すべての $l \leq k$ と $j \in A_{1}(i)$ について $x_{\tilde{j}}^{l-1}=\infty$ および $x_{j}^{k} \neq \infty$ となる $\tilde{\jmath} \in A_{1}(i)$ が 存在する. $k_{i}$ の定義から， $k_{f}=k$ となる. 㷌納法の仮 定により， $k<k_{j} \Rightarrow x_{j}^{k}=\infty$ およびすべての $l \geq k$ につ いて $k \geq k_{j} \Rightarrow x_{j}^{l}=k_{j}=x_{j}^{*}$ が成立する.この式と $x_{i}^{k+1}$ $=1+x_{j}^{k}$ から, すべての $l \geq k+1$ について $x_{i}^{l}=1+k_{\tilde{\tau}}$ $=x_{j}^{*}$ が成立する. 故に式(15) は $k+1 \geq k_{i}$ の場合に成 立する。

$k+1>k_{i}$ の場合は, 㷌納法の仮定により結論が成 立する. 帰納法完了.

後で使用するために，以下の補助定理を記してお $<$.

補助定理 1 各ノード $i \neq d$ において,

$$
k_{j} \geq k_{i}-1 \text { for all } j \in A_{1}(i),
$$

が成立し，等号が成り立つ $j \in A_{1}(i)$ が存在する.

証明 2 式(11)と $k_{i}$ の定義による。

補助定理 2 すべての $k \geq 1$ とノード $i \in\left\{h_{1}, h_{2}, \cdots\right.$, $\left.h_{(n-1)}\right\}=\{1,2, \cdots,(n-1)\}$ について, 次式が成立.

$$
\begin{aligned}
k_{h 1} \leq k_{h 2} \leq & \cdots k_{h(n-1)} \\
& \Rightarrow x_{h 1}^{k} \leq x_{h 2}^{k} \leq \cdots x_{h(n-1)}^{k} .
\end{aligned}
$$

証明 3 繰り返し数 $k=k_{p}$ のとき, $k_{p} \geq k_{i}$ なるす べての $\underline{i}$ に対して, 式(15)から $x_{\underline{i}}^{k}=k_{\underline{i}}$ が得られ, 結 論が成立する， $k_{p}<k_{i}$ なるすべてのてに対して，式 (14) から $x_{i}^{k}=\infty$ が得られ, $x_{i}^{k} \geq x_{i}^{k}$ となり, $て$ に対し

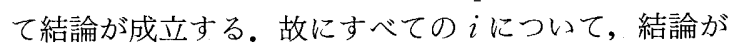
成立する.

補助定理 3 各ノード $i \neq d$ において,

$$
x_{j}^{k}=x_{i}^{k}-1
$$

なる $\tilde{j} \in A_{1}(i)$ が存在する.

証明 4 式(11)と(15) から,すべての繰り返し数 $k$ $\geq k_{i}$ について結論が成立する。 $\infty=\infty-1$ の場合を含 めれば, 式(11)と(14)から,すべての繰り返し数 $k \geq$ 1 について結論が成立する.

\section{3 非単位コストアークネットワーク}

次に，仮定 1 を緩めて，各アークが任意の正の整数 のコストを保有できることとする。すなわち， $a_{i j}$ は 任意の正の整数を取り得る. 前述のアークコスト $=1$ の場合の結果が使用できるようにするため,すべての $i, j$ について, アーク $(i, j)$ にダミーノード $i_{1}, i_{2}, \cdots$, $i_{m}$ を挿入し, アーク $(i, j)$ を量子化する.

ダミーノードではアークの枝分かれはないので, ダ ミーノードの挿入によってネットワークのトポロジー は変化しない，さらに，ノードにはコストが付与され ていないので, ダミーノードの挿入によって, 経路 
Vol. 4, No. 3 (1997)

$(i, j)$ の総コストが変化することもない.この量子化 されたネットワークでは, 仮定 1 のもとでの前述の議 論が適用できる.

ベルマン・フォードアルゴリズムの変形として次式 を示す.

\section{命題 2}

$$
\begin{aligned}
& x_{i}^{k}=\min _{j \in A(i)}\left(a_{i j}+x_{j}^{k-a_{i j}}\right), \text { for } i \neq d, \\
& x_{d}^{k}=0
\end{aligned}
$$

証明 5 アーク $(i, j)$ はダミーノード $i_{1}, i_{2}, \cdots, i_{m}$ を 挿入することによって量子化でき, 経路 $\left\{\left(i, i_{1}\right),\left(i_{1}\right.\right.$, $\left.\left.i_{2}\right), \cdots,\left(i_{m}, j\right)\right\}$ が得られる. 但し $m=a_{i j}-1$ である. ここで $i_{0}=i$ および $i_{m+1}=j$ と記す。式(12)から， $x_{i}^{k}$ $=1+x_{\tilde{n}}^{k-1}$ なる $\tilde{\imath}_{1} \in A_{1}(i)$ が存在する. 但し $A_{1}(i)$ は 量子化されたネットワークに扔ける，ノード $i$ の隣接 ノードの集合である。そこで $x_{\tilde{i}}^{k-1}=1+\min _{l \in A_{1}(\tilde{\tilde{n}})} x_{l}^{k-2}$ が得られる. ダミーノード $i_{h},(h=1,2, \cdots, m)$ では枝 分かれが無く， 2 個の隣接ノードしか保有しないの で, $A_{1}\left(i_{h}\right)=\left\{i_{h-i}, i_{h+1}\right\}$ となり, $x_{\tilde{n}}^{k-1}=1+\min \left(x_{\tilde{\tilde{k}}}^{k-2}\right.$, $\left.x_{i}^{k-2}\right)$ となる。 $x_{i}^{k}=1+x_{\tilde{\hbar}}^{k-1}$ および式(17) と式(18)か ら， $x_{\bar{i}}^{k-2} \leq x_{i}^{h-2}$ となる. 故に $x_{\tilde{\hbar}}^{h-1}=1+x_{\bar{\hbar}}^{k-2}$ および $x_{i}^{k}=2+x_{i z}^{k-2}$ を得る. 同様の作業により, $x_{i}^{k}=m+$ $x_{i m}^{k-m}=a_{i j}+x_{j}^{k-a_{i j}}$ を得る.

量子化前のネットワークの, すべての $j \in A(i)$ を 考慮することにより，結論を得る。

また，一般にアークコスト $\neq 1$ のネットワークの $k_{i}$ は次式に従う。

命題 3 各ノード $i \neq d$ に扔いて次式が成立し,

$$
k_{i}=\min _{j \in A(i)}\left(a_{i j}+k_{j}\right),
$$

また， $k_{d}=0$ となる.

証明 6 アーク $(i, j)$ はダミーノード $i_{1}, i_{2}, \cdots, i_{m}$ を 挿入することによって量子化でき, 経路 $\left\{\left(i, i_{1}\right),\left(i_{1}\right.\right.$, $\left.\left.i_{2}\right), \cdots,\left(i_{m}, j\right)\right\}$ が得られる. 但し $m=a_{i j}-1$ である. ここで $i_{0}=i$ および $i_{m+1}=j$ と記す. 式(16)により, $l$ $=0,1, \cdots, m$ については $k_{i l+1}+1 \geq k_{i l}$, 抢よび $l=1,2$, $\cdots, m+1$ については $k_{\left.i_{l-1}\right)}+1 \geq k_{i l}$ が得られ, $l=1,2$, $\cdots, m$ について，少なくとも1個の等号が成立する. これらの不等式を足し合わせることにより $, l=0,1$, $\cdots, m+1-p$ にいて $k_{i l+p)}+p \geq k_{i l}$ と, $l=p, p+1$, $\cdots, m+1$ について $k_{i(l-p)}+p \geq k_{i l}$ が成立する。ここで $p=0,1, \cdots, m+1$ であり, $l=p, p+1, \cdots, m+1-p$ に ついては少なくとも 1 個の等号が成立する. $p=m+1$ と $l=0$ の場合は, $i_{0}=i$ 抢よび $i_{m+1}=j$ および $m+1$ $=a_{i j}$ なので, $k_{j}+a_{i j} \geq k_{i}$ を得る.

量子化前のネットワークの, すべての $j \in A(i)$ を 考慮することにより， $k_{j}+a_{i j}=k_{i}$ なる $j \in A(i)$ が存
在する、故に，結論を得る。

\section{4 ノードへのコストの付与}

これまでの議論では，ノードはコストを保有しない としていたアアークコストを式（8)のように変更する ことにより，ノードへコストを付与することができ る.すなわち， $a_{i j}=\widehat{a}_{i}+\bar{a}_{i j}$ とする。但し $\widehat{a}_{i}$ はノ一 ドの $i$ のコトで， $\bar{a}_{i j}$ はアーク $(i, j)$ のコストであ る.ノード $i$ のノードコスト $\widehat{a}_{i}$ は, ノード $i$ から出 ていくアークに加算され，ノード $i$ にってくるアー クには加算されない.ここでは，ノードコスト $\widehat{a}_{i}$ は，ノードを通過したときに加算されると仮定してい る。もし発信ノード $i$ にコスト $\widehat{a}_{i}$ を付与したくない 場合には， $\widehat{a}_{i}=0$ と設定すればよい.

\section{5 ニューラルネットアルゴリズムの道出}

前述の単位コストアークネットワークの議論におい て, 繰り返し数 $k$ が $k_{i}$ 以上の場合は, ノード $i$ から あて先 $d$ までの最小コスト経路のコスト $x_{i}^{*}$ は $k_{i}$ に 等しくなり, 最小コスト経路のコストと, 繰り返し回 数は一対一対応する. 故に経路のコストと繰り返し回 数の両方をフォローする必要はなく, どちらか一方で よい. 従って, 基本式(10)に抢いて， $x_{i}^{h}$ の值が $\infty$ か ら正整数に変化するときの繰り返し数 $k_{i}$ にさえ注意 していれば， $x_{i}^{k} や x_{j}^{k-1}$ の値は詳細にフォローする必 要がない.

さらに, 初期值 $x_{i}^{0}$ は $\infty$ である必要はなく, 非初期 值と明確に区別できる任意の值とすることができる. 重要な点は, あて先 $d$ から出発した非初期值が, 隣 接ノードを通して次々と伝搬していく点である。ま た，一般に，アークコスト $\neq 1$ のネットワークに扔い ては，アークを量子化することによって，アークコス 卜 $a_{i j}$ が繰り返し数の遅延に変換できることを, 式 (19) と式(20)で示した. 故に我々は, ベルマン・フォ ードアルゴリズムの変形として次式を示す。

\section{命題 4}

$$
\begin{aligned}
& x_{i}^{k}=\left\{\begin{array}{lr}
\text { 活性 } & i \neq d \text { で, } x_{j}^{k-a_{i j}} \text { が活性な } \\
& j \in A(i) \text { が存在する場合 } \\
\text { 不活性 } & i \neq d \text { で, 上記以外の場合 }
\end{array}\right. \\
& x_{d}^{k}=\text { 活性. }
\end{aligned}
$$

但し初期条件は $x_{d}^{0}=$ 活性, $i \neq d$ の場合は $x_{i}^{0}=$ 不活 性とする。 また, $k-a_{i j}<0$ の場合は $x_{j}^{k-a_{i j}}=$ 不活性 とする。最小コスト経路のコスト $x_{i}^{*}$ は， $k_{i}$ と等し い.

命題 4 の式(21) からニューラルネットの刺激の伝搬 式( 2 )を得る.

ここで, 命題 1 より, $x_{i}^{k}$ は一度活性化したら不活 性には戻らないことがわかる。命題 4 に従って $x_{i}^{k}$ の 
変換を繰り返し，すべての $i$ にいて $x_{i}^{k}$ が活性化し たときに，最小コスト経路のコスト $x_{i}^{*}$ の分布が得ら れる。

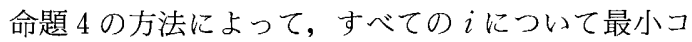
スト経路のコスト $x_{i}^{*}$ の分布を得られたとする。明ら かに，各 $x_{i}^{*}$ の值は，1個またはそれ以上の最小コス 卜経路 $(i, \cdots, d)$ に付随するものである. 最小コス卜 経路は, 式(21)に扔いて， $x_{i}^{k} か ゙$ 活性化する要因とな ったノード $j \in A(i)$ から構成されている。 $i \neq d$ なる ノード $i$ に扔いて, 活性化要因隣接ノード $P(i)$ は, 繰り返し数 $k_{i}$ のときに $x_{i}^{k}$ が活性化する要因となった ノード $j \in A(i)$ の集合である. $P(i)$ はノード $i$ に依 存し，ノード $i$ を通る経路とは独立である. 3.3 節で 述べた $w_{i j}^{*}$ は, $P(i)$ と $w_{i j}^{*}=1 \Longleftrightarrow j \in P(i)$ なる関係に あり, $P(i)$ と同等の概念を表わす. $i=1, \cdots, n$ につ いての $w_{i j}^{*}$ の集合が最効率的ネットワークとなる. 式 (21) から $w_{i j}^{*}$ を求める手順が式 (4) に相当する.

\section{5. 適用法と評価}

\section{1 ディジタル論理回路による実現法}

本節では，3 章で提案したアルゴリズムをハードウ エアディジタル論理回路で実現する方法を示す． 3 章 で提案した手法と 4.1 節で述べた従来の動的計画法に よる手法との最大の差異は, 従来方法の状態変数 $x_{i}^{k}$ 㹥非負の実数值をとり得るのに対して, 提案方式の状 態値 $x_{i}^{k}$ は 1 と002 値のみをとるという点である. 故に提案方式の漸化式は論理演算で表現することがで きる.

すなわち, 神経方程式 (3) と記憶方程式 ( 5 ) は次の ように表すことができる。

$$
\begin{aligned}
& x_{i}^{k}=\left(x_{j_{1}}^{k-w_{i j_{1}}} \bigvee x_{j_{2}}^{k-w_{i j_{2}}} \bigvee \cdots \vee x_{j m_{i}}^{\left.k-w_{i j m_{t}}\right)}, \text { for } i \neq d,\right. \\
& x_{d}^{k}=1 \\
& w_{i i_{t}}^{*}=S\left[\left(x_{i}^{k} \oplus x_{i}^{k-1}\right) \wedge x_{j t}^{k-w_{i j}}\right]
\end{aligned}
$$

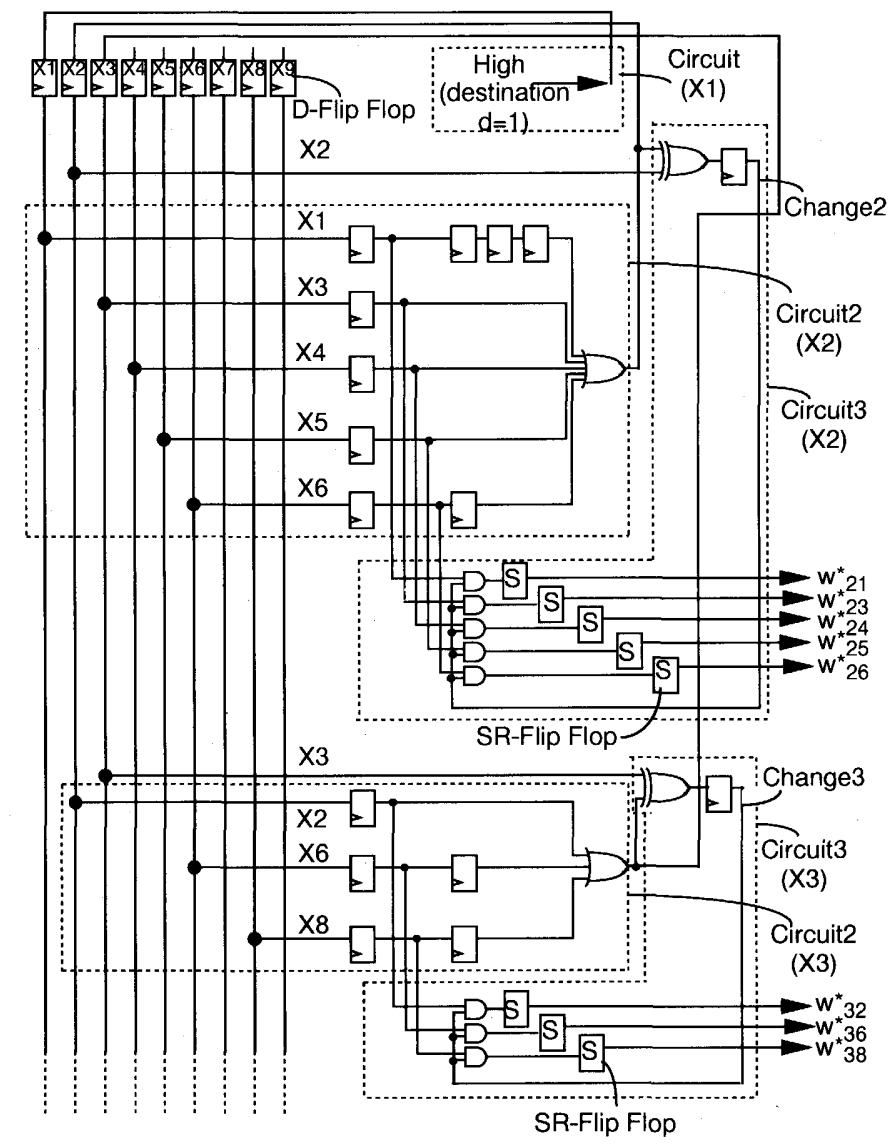

Fig. 2 Hardware digital logic circuit. 提案方式をディジタル論理回路で実現した例 (5.1 節で説明) 
但し $l=1,2, \cdots, m_{i}$ で $j_{1}, j_{2}, \cdots, j_{m_{i}}$ は $i$ の隣接ニュー ロン, $\vee$ は論理和, $\oplus$ は排他的論理和, $\wedge$ は論理積 を示す。また $S[x]$ はセットを表す関数で, $x$ が一度 1 になったら，リセットするまで1を保持する.

図 2 に示す回路は, 図 1 (b)のニューロン 2 の状態 数 $x_{2}^{k}$ およびニューロン 3 の状態数 $x_{3}^{k}$ を式 (22) に従 って変化させ, 式(23) に従ってシナプス荷重 $w_{2 j}^{*} お よ$ び $w_{3 j}^{*}$ を得るものである. 但しあて先は $d=1$ として いる。また，式(22)おるび(23)の 1 を高電位， 0 を低 電位と打いている. 初期条件としては, $i \neq d$ のフリ ップフロップおよびシフトレジスタを 0 にリセットす る.

図 2 の回路では, 状態数 $x_{i}^{h},(i=1, \cdots, 9)$ の值を $\mathrm{X} 1$ から X 9 の D フリップフロップ(D-FF) に保持す る. 式(22)による状態数 $x_{2}^{k}$ の更新は図 2 の Circuit 2(X 2) で, 状態数 $x_{3}^{k}$ の更新は Circuit 2(X 3) で 実現している。また，式(23)による荷重 $w_{2 j}^{*}$ の計算は 図 2 の Circuit 3(X 2) で, 荷重 $w_{3 j}^{*}$ の計算は Circuit 3 (X 3) で実現している.また, 式(22)の $x_{d}^{k}=1$ から X 1 は高電位に固定となるが, これは図 2 の Cir$\operatorname{cuitl}(\mathrm{X} 1)$ で実現している.また, 式(23)の関数 $S$ は 図 2 のSRフリップフロップで害現している.

図 1 ( b ) の他の二ューロンについても同様に回路を 構成すると, 最効率的ネットワークを出力する回路が 得られる。

これらの回路で最効率的ネットワークを求めるのに
要する時間は，原理的に，

アークコストのステップ数 $\times$ ノド数 $n \times$ 基本 クロック時間

を越えない.

\section{2 評価}

本節では，提案方式の計算時間を評価する．図 3 は 日本の 56 都市をノードとして 72 本のアークで接続し た図である，この図において，東京をあて先 $d$ とし た場合の最効率的ネットワークを計算するのに要する 時間を求める. 都市間のアークのコストは, 動的計画 法のベルマン・フォードアルゴリズムで計算する場合

Table 2 Distance between 56 cities and the cost class for each unit distance.

56都市間の距離と, 単位距離別 コストクラス (5.2節で説明)

\begin{tabular}{|c|c|c|c|c|c|c|c|c|}
\hline \multicolumn{3}{|c|}{ 都市名都市名距離 } & \multicolumn{3}{|c|}{ 単位距離 $(\mathrm{km})$ 号 } & \multicolumn{3}{|c|}{ 列コストクラス } \\
\hline & & $(\mathrm{km})$ & 20 & 25 & 50 & 100 & 150 & 200 \\
\hline 札㹸 & 可館 & 57 & 8 & & & 2 & 4 & \\
\hline 札幌 & $\bar{F}$ & 286 & 15 & 12 & 0 & 4 & & \\
\hline 札幌 & 潟 & 614 & 31 & 25 & 13 & & & \\
\hline 函 & & 106 & & $\Rightarrow$ & & & & \\
\hline 八戸 & 盛岡 & 95 & ग & 4 & 2 & & 1 & \\
\hline & & & : & 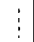 & $\vdots$ & : & & \\
\hline 島 & & 50 & 3 & 3 & & 3 & 1 & \\
\hline 高松 & & 33 & 7 & 6 & 3 & 2 & & \\
\hline 松山 & 鹿児島 & 320 & 17 & 13 & 7 & 7 & 3 & \\
\hline 七九州 & 福岡 & 50 & 3 & 2 & & 4 & 1 & \\
\hline 九州 & 鹿児! & 250 & 13 & 10 & 5 & 3 & 2. & \\
\hline
\end{tabular}

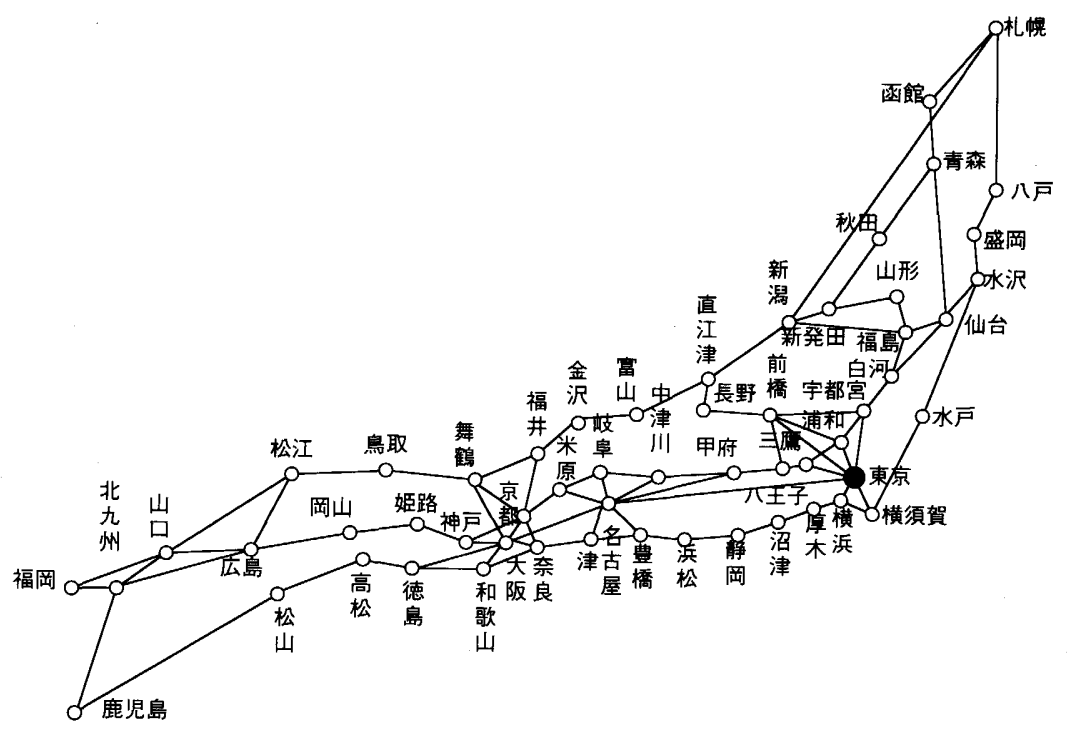

Fig. 3 Cities of Japan (56 Cities, 72 Connections).

56 都市・72 接続の日本の都市の接続図 (5.2 節で説明) 
には実距離 $(\mathrm{km})$ を用いるが，提案方式で求める場合 には実距離 $(\mathrm{km})$ を単位距離 $(\mathrm{km})$ で量子化したコスト クラスを用いる.即ち(コストクラス) $=\lfloor$ (実距離) $/$ (単位距離) $\rfloor+1$. 但し， $\lfloor x\rfloor$ は $x$ 整数部とする. 都市 間の実距離と, 単位距離が $20,25,50,100,150$, $200 \mathrm{~km}$ の場合のそれぞれのコストクラスを表 2 に示 す(一部のみ). 提案方式の性能を評価する上では，各

Table 3 Relation between the unit distance and the number of cost classes.

単位距離とコストクラス数の 関係 $(5.2$ 節で説明)

\begin{tabular}{|l|r|r|r|r|r|r|}
\hline 単位距離(km) & 20 & 25 & 50 & 100 & 150 & 200 \\
\hline コストクラス数 & 31 & 25 & 13 & 7 & 5 & 4 \\
\hline
\end{tabular}

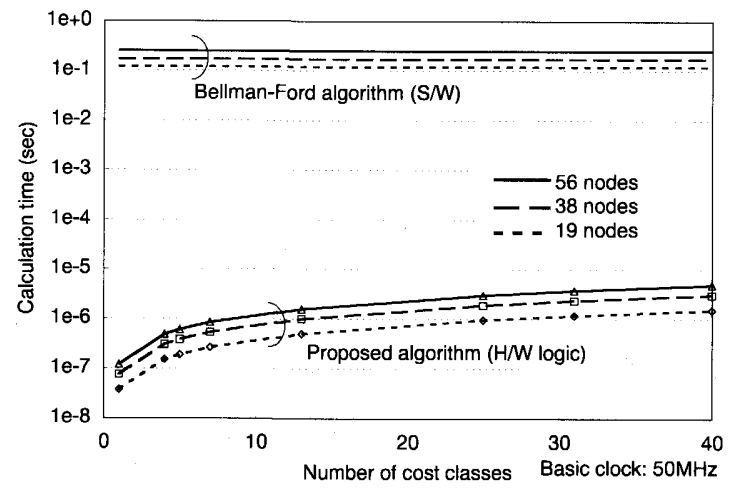

（a）提案方式をハードウェア論理回路で実現した場合

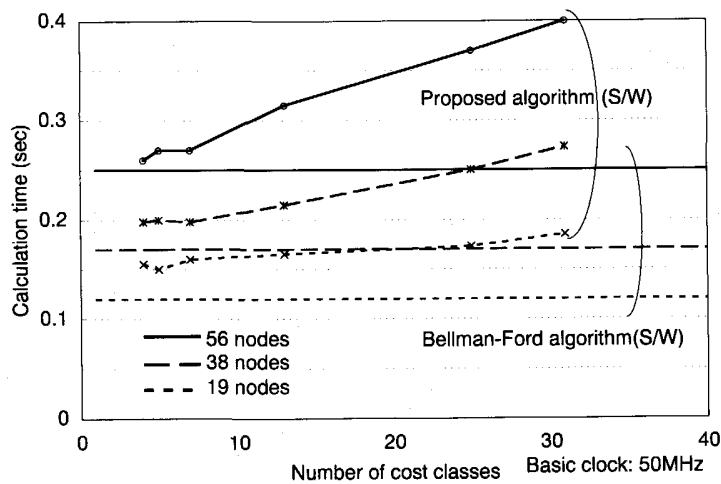

（b）提案方式をソフトウェアで計算した場合

Fig. 4 Evaluation of calculation time.

提案方式の最効率的ネットワークの計算時間 と, ベルマン・フォードアルゴリズムによる 計算時間の比較 (5.2 節で説明)
単位距離に対する最大コストクラス，即ちコストクラ スの選択肢として準備するべきコストクラスの数が重 要なパラメータとなるが，これを表 3 に示す.

図 3 で東京をあて先 $d$ とした場合の最効率的ネッ トワークを，計算するのに要する時間を，ベルマン・ フォードアルゴリズムと，提案方式をディジタル論理 回路で実現して求めたものを，図 4 (a)に示す。ディ ジタル論理回路は 5.1 節で述べた方法に倣って構成す るものとし，基準クロックを $50 \mathrm{MHz}$ として式(24) に従って計算時間を算出した。ベルマン・フォードア ルゴリズムについては, 距離は倍精度浮動小数点変数 とし，基本クロック $50 \mathrm{MHz}$ の Sun SPARC station 10 で実測した。な押，図4（a)には，図 5 (a) 亿示 す 38 都市 67 接続の場合，および図 5 （b ）に示す 19 都市 37 接続の場合の計算時間も示してある。

ベルマン・フォードアルゴリズムでの計算時間は横 軸のコストクラス数とは無関係で，56 都市の場合 0 . 25 秒，38 都市の場合 0.17 秒，19 都市の場合 0.12 秒 となっている．提案方式ではコストクラス数に比例し て計算時間は増加するが，56 都市でコストクラス数 4 (単位距離 $200 \mathrm{~km}$ ) の場合 480 ナノ秒，コストクラ 又数 31 (単位距離 $20 \mathrm{~km}$ ) の場合 3.72 マイクロ秒とな り，ベルマン・フォードアルゴリズムの場合に比べて 4 桁から 6 桁小さくなっている.

なお，最効率的ネットワークを計算するのにワーク ステーションを用いる場合は，図 4（b）に示すよう に，提案方式を用いてもべルマン・フォードアルゴリ ズムによる場合に比べて計算時間が短縮されず，わず かに増加する。これは，ワークステーションでは変数 が 1 ビットだからといって計算が高速になるわけでは ないので，普通に計算する限りでは提案方式の特性を 生かすことができないうえに，変数を量子化すること による手数増加があるからである。

ここで，ベルマン・フォードアルゴリズムをハード ウェア論理回路で実現した場合の計算時間はどうか, という疑問が発生する。提案方式は式 (22)，(23) に示 すように 1 と00論理式で表わすことができるので, AND，OR 等のディジタル論理素子を用いて通常の 技術者により容易に装置化できる。一方，式(10)で表 現されるべルマン・フォードアルゴリズムをハードウ エア論理回路で実現することは，原理的には可能であ るが，現実的には非常に困難である. 式(10)のハード ウェアでの実現方法としては，1）漸化式を全て 0 と 1 とに展開して表現し，専用論理回路を設計する，2)ア ルゴリズムを遂行するソフトウェアをファームウェア 化し，汎用プロセッサを用いることが考えられる，1） 


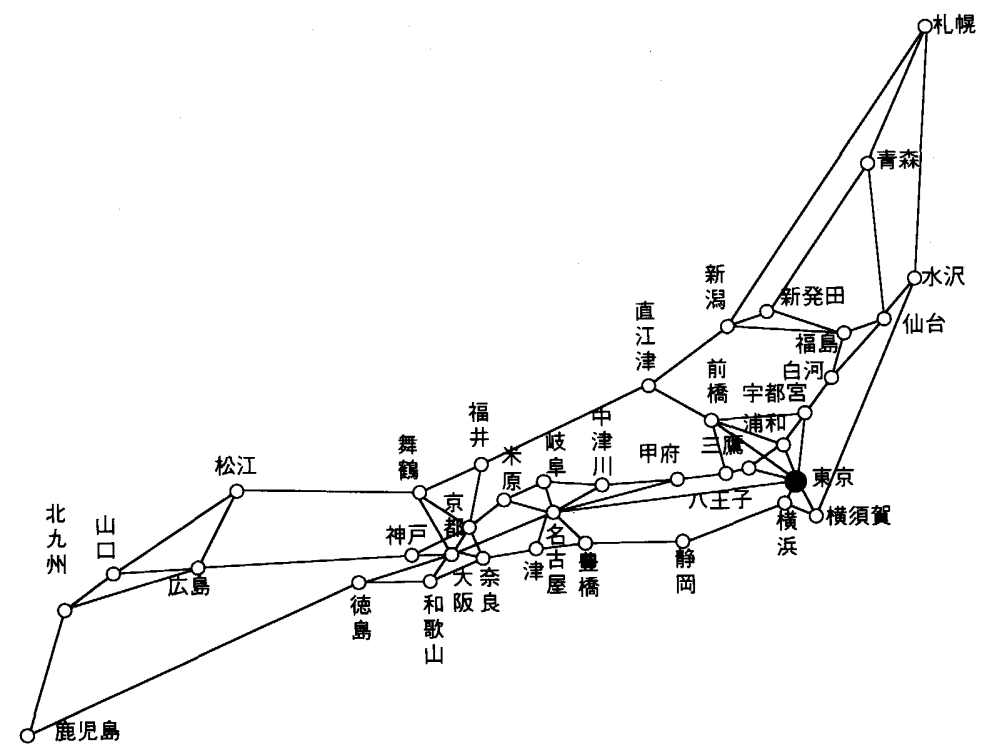

(a) 38 Cities, 67 Connections

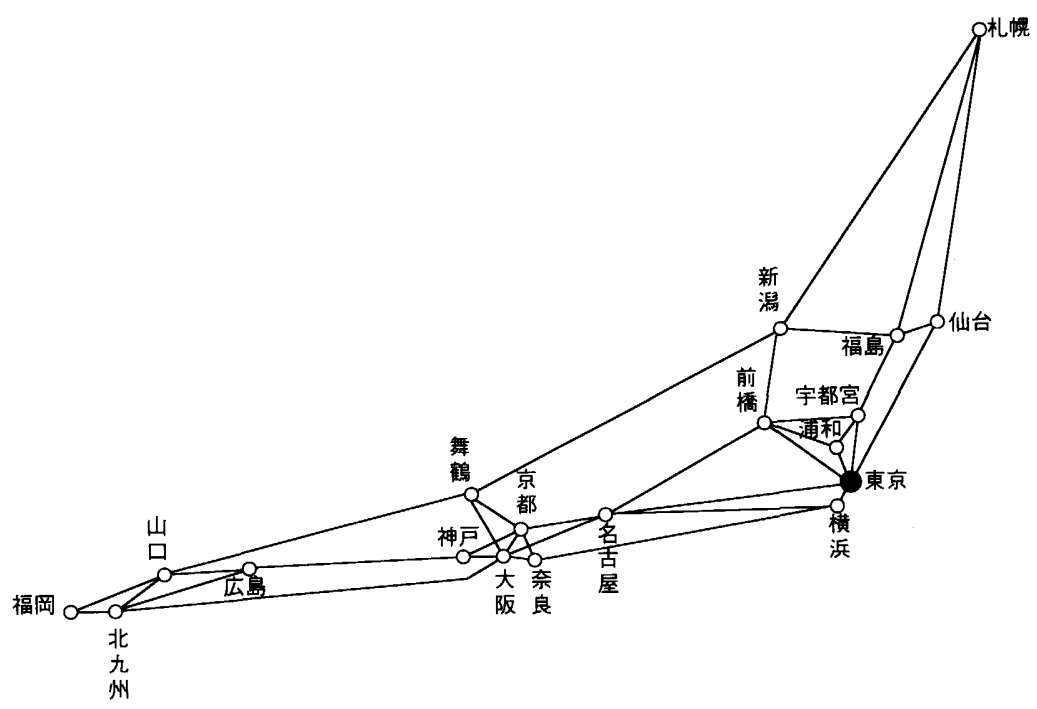

(b) 19 Cities, 37 Connections

Fig. 5 Cities of Japan. (a ) 38 都市・67 接続，(a ) 19 都市・37 接続の 日本の都市の接続図 (5.2 節で説明)

は原理的には可能であり，計算速度も高速となるが， 回路規模が非常に大きくなり，現実的ではない，2）は 現実的な方法であるが，原理的にはソフトウェアをプ ロセッサで遂行しているので，ハードウェア論理回路 の場合に比べて，計算時間は非常に遅くなる。

\section{3 提案方式の有効性}

提案方式の特長として, 前節で評価した高速性の他 に LSI 化の容易性をあげることができる．図 2 で示 すようなディジタル論理回路は，容易に LSI 化でき， ゲート規模も小さいので高度な集積化が可能である. また，図 2 の例では通信ネットワークのノード間の接 
続に従って回路の結線が固定されているが，ノード間 接続の有無をソフトウェア制御して,アーク接続の変 化に柔軟に対応させることもできる。一例として，図 3 の規模のネットワークの経路設計をする汎用 LSI として，64ノード，コストクラス数 4,64 ノード中 8 ノードは他の全ノードと接続可, 56 ノードは近隣 16 ノードとのみ接続可という条件で, $460 \mathrm{k}$ ゲートの 回路規模となる。これは $2 \sim 3$ 個の LSI で実現可能で ある。経路設計回路の LSI 化により，実システムへ の経路設計機能の実装を安価で小規模に行なうことが できる。例えば，広域 LANの全てのルー夕に経路設 計機能を実装するためには，並列計算機を組み込んで 従来方式により経路設計を行なうよりも，提案方式を LSI 化して組み込むほうが，コスト，スペース，計算 時間の点からはるかに容易である。

一方，この方式はアークコストのステップ数が数個 〜数十個の場合には有効であるが，一般の計算機の変 数のように精度をあげることは実質的には不可能とな る.しかし，上記のような高速性および高度な集積性 により, 従来の方式では時間的にも処理資源的にも最 適化計算が不可能であった分野での最適化が可能とな る. 従来の解法が, 長時間かけて厳密な最適解を求め る「設計」に適していた方法であったのに対し，提案 方式は短時間で粗い最適解を求める実時間の「制御」

に適しているといえる，例えば電話回線の動的ルーチ ングでは, 処理量の制限等から最適経路設計が困難で あったが, 提案方式程度の精度でも適用することがで きれば，十分有効となる。

\section{6. ま と め}

ニューラルネットによる離散系最短経路問題の実時 間制御への適用法を提案した。提案方式は動的計画法
に基くものであるが，ニューラルネットの 2 値性やア ルゴリズムの単純繰返性をいかしてディジタル論理回 路で実現することができ, 高速化, 高度な集積化が可 能である.これにより，従来の方式では時間的にも処 理資源的にも最適化計算が不可能であった分野での最 適化が可能となる。また，ノード間のアークあるいは ニューロン間のシナプス結合には，向きと重みを付加 できるので，結合係数にノードのコスト，アークの容 量など多量の要素を組み入れる等の応用が可能とな り，一般性の高いものとなっている.

\section{参 考 文 献}

1) Tank, D. W., Hopfield, J. J. (1986): Simple "Neural" optimization networks: An A/D converter, signal decision circuit, and a linear programming circuit, IEEE Trans. on Circuits and Systems, Vol. 33, No. 5, pp. 533-541

2) Kennedy, M. P., Chua, L. O. (1988): Neural networks for nonlinear programming, IEEE Trans. on Circuits and Systems, Vol. 35, No. 5, pp. 554-562

3) Lemmon, M. (1991): 2-Degree-of-freedom robot path planning using cooperative neural fields, Neural Computation, Vol. 3, No. 3, pp. $350-362$

4) 田中健一, 堤 一義 (1992): 運動系二ューラルネ ットワークとロボット制御，システム/制御/情報, Vol. 36, No. 10, pp. 653-660

5）河東晴子, 田中健一, 大島一能 (1996): ニューラル ネットによる最小ホップ数経路設計方式の提案, 電子情報通信学会論文誌 B-I, Vol. J79-B-I, No. 12, pp. 765-769

6) Bertsekas, D. P., Tsitsiklis, J. N. (1989): Parallel and Distributed Computation. (Sec. 4. 1) New Jersey: Prentice Hall 